\title{
A Theoretical Study of E-Loyalty
}

\author{
Manjari Lal ${ }^{1 *}$ and Hemant Katole ${ }^{2}$ \\ ${ }^{1}$ IndSearch Institute of Management Studies and Research, Bavdhan, Pune, Maharashtra, India \\ ${ }^{2}$ PUMBA, Department of Management Sciences, Savitribai Phule Pune University, Ganeshkhind, Pune, \\ Maharashtra, India
}

\section{ABSTRACT}

Indian consumers have predominantly been dependent on the small neighborhood store (the unorganized sector). Inspite of the development of the organized sector (the organized brick and mortar stores and e commerce websites), it constitutes only 10 percent of the complete retail market. The experience for most consumers during the initial phase of the pandemic was not very good with some essential good websites, when they tried to make purchases online (ERetail.com, Mar 25, 2020). Later there was a change and the websites were better equipped to handle the rush for online purchases. Post the Covid 19 Pandemic, there is a shift in the way consumers make their purchases. The E-Commerce market had a sudden shift - the change that would have happened in 3 to 5 years time in the future (as was predicted), but was being seen in a few months. In a global consumer survey, there is an increase in the proportion of online purchases ( 1 in 5 grocery online purchasers were first timers and 1 in 3 for people who were more than 56 years of age) (Accenture 2020). Considering the shift in consumer behaviour, e loyalty is an important aspect of study for the e retailer.

KEY WORDS: E-LOYALTY, RETAIL, ONLINE, CONSUMER.

\section{INTRODUCTION}

(Reichheld \& Schefter, 2000) in the article "E-Loyalty: Your Secret Weapon on the Web" in Harvard Business Review have stated that there is a perception in people's mind that e loyalty does not exist but that is not true. Contrary to belief, loyalty online is very much prevalent. But if sellers online fail to get the loyalty of their online existing and profitable customers then they will be selling to buyers who purchase online from sites that sell at a comparatively lower price. According to them, trust is the most essential element dominating the online market and not price.

Biosc Biotech Res Comm P-ISSN: 0974-6455 E-ISSN: 2321-4007

\section{crossef}

Identifiers and Pagination

Year: 2021 Vol: 14 No (5) Special Issue

Pages: $17-20$

This is an open access article under Creative

Commons License Attribn 4.0 Intl (CC-BY).

DOI: $h t t p: / / d x$.doi.org/10.21786/bbrc/14.5/3
As per the ibef report for November 2020, the Indian online retail market in 2017 was 17.8 billion USD and was estimated to cross 60 billion USD in 2020. The Indian Retail Market in India is 25\% of the total organized market and the estimation is $37 \%$ by 2030 . Besides 15 to 20 thousand pin-codes in India are already covered by online retailers (the total pin codes is approximately one hundred thousand).

According to a December 2020 report "Ecommerce in India" by ecommerceDB, $40 \%$ of the population shop online and net online sales in Indian E Commerce market were 33 billion USD in 2019. All these figures speak of the growth of the online market and so e loyalty is an important factor of study.

Literature Review: The research papers on e loyalty have been written with reference to technological products, books, travel and banking services. These studies have been done majorly in the United States. 
The definition of e loyalty as has been proposed by (Toufaily et al., 2013) “the customer's willingness to maintain a stable relationship in the future and to engage in a repeat behavior of visits and/or purchases of online products/service, using the company's website as the first choice among alternatives, supported by favorable beliefs and positive emotions toward the online company, despite situational influences and marketing efforts that lead to transfer behavior".

Table 1. Consumer E loyalty references:

\begin{tabular}{|c|c|c|}
\hline Author & Important characteristics of e loyalty & Remarks \\
\hline (Nagvadia \&t Bhatt, 2020) & $\begin{array}{l}\text { The authors of the research have } \\
\text { done an exploratory factor } \\
\text { analysis and identified the } \\
\text { following : ease in searching, } \\
\text { in usage, flexibility, secure } \\
\text { transactions, honesty, privacy, } \\
\text { enjoyment, good experience, } \\
\text { as important for online loyalty. }\end{array}$ & $\begin{array}{l}\text { The study was done in } \\
\text { Ahmedabad only. As suggested } \\
\text { by the authors, a comparative study } \\
\text { between urban and rural areas } \\
\text { could be done. }\end{array}$ \\
\hline (Giao et al., 2020) & $\begin{array}{l}\text { This research confirmed the role } \\
\text { of e-satisfaction in predicting } \\
\text { customers' e-loyalty and that it } \\
\text { makes the customer have positivity } \\
\text { about sellers online. }\end{array}$ & $\begin{array}{l}\text { The study was done in Vietnam. } \\
\text { The study suggested that the } \\
\text { research can be done to study } \\
\text { the impact on the basis of } \\
\text { demographics of the consumers. }\end{array}$ \\
\hline (Rachbini, 2018) & $\begin{array}{l}\text { The results of this study say } \\
\text { that on the Internet, trust, } \\
\text { perception of risk, and perception } \\
\text { of benefit have a great impact on } \\
\text { customer's intention to purchase. }\end{array}$ & $\begin{array}{c}\text { The study was carried } \\
\text { out in Indonesia only with a } \\
\text { limited sample. }\end{array}$ \\
\hline (Chincholkar et al., 2017) & $\begin{array}{l}\text { Product quality, price, discounts and } \\
\text { offers, less time to deliver the } \\
\text { product are important factors } \\
\text { that impact on online buyer } \\
\text { and women are more loyal to websites. }\end{array}$ & $\begin{array}{l}\text { The data for the study } \\
\text { was from Mumbai only } \\
\text { and without consideration } \\
\text { for any product / category }\end{array}$ \\
\hline (Jamaludin \& Ahmad, 2015) & $\begin{array}{l}\text { The study states that if people visit } \\
\text { the website again then there } \\
\text { are higher chances of trust, } \\
\text { loyalty to and purchase from the website. }\end{array}$ & $\begin{array}{l}\text { The target group for the } \\
\text { study was undergraduate } \\
\text { students in Kuala Lumpur. }\end{array}$ \\
\hline (Tontini et al., 2015) & $\begin{array}{l}\text { Service speed, accessibility has } \\
\text { an enforcing effect on satisfaction } \\
\text { for the customer leading to e loyalty. } \\
\text { The paper also speaks of importance } \\
\text { of recovery in case of fault for loyalty. }\end{array}$ & $\begin{array}{l}\text { The study is exploratory in } \\
\text { nature and as suggested a } \\
\text { study should be done to } \\
\text { study the relationship between } \\
\text { dimensions of online } \\
\text { retail stores quality. }\end{array}$ \\
\hline (Toufaily et al., 2013) & $\begin{array}{l}\text { The paper makes a mention of } \\
\text { various online customer } \\
\text { loyalty definitions. } \\
\text { The variables of customer characteristics that } \\
\text { are important for e loyalty have been grouped } \\
\text { as: Relational (trust, satisfaction, commitment) } \\
\text { Perceptional (risk, value, switching cost) } \\
\text { Psychological (aggressiveness, motivations, } \\
\text { attitude, repeat purchase intention) } \\
\text { Relationship with technologies (user experience, } \\
\text { information of the website, preferences) } \\
\text { The variables of service/ product characteristics }\end{array}$ & $\begin{array}{l}\text { A theoretical study that states } \\
\text { that research needs to focus } \\
\text { on the concept of e loyalty } \\
\text { from the angle of commitment, } \\
\text { building strong relationships, } \\
\text { and not only satisfaction }\end{array}$ \\
\hline
\end{tabular}




\begin{tabular}{|c|c|c|}
\hline & $\begin{array}{l}\text { that are important for e loyalty are stated as: } \\
\text { Quality, price perception, discounts } \\
\text { \& rewards, volume of purchase. } \\
\text { The retailer characteristics are: strategy, } \\
\text { reliability, competency, IT policies, support service. } \\
\text { The website characteristics under consideration are: } \\
\text { design, security, ease of use, content, } \\
\text { trustworthiness, empathy, credibility, customization. }\end{array}$ & \\
\hline (Kassim \&t Abdullah, 2008) & $\begin{array}{l}\text { This paper speaks of satisfaction } \\
\text { and secure feeling leading } \\
\text { to trust and reliability in } \\
\text { the online market. }\end{array}$ & $\begin{array}{l}\text { The study was on a small } \\
\text { sample. Cultural influences } \\
\text { can be studied in the } \\
\text { case of online retailers. }\end{array}$ \\
\hline (Joe ilsever, 2007) & $\begin{array}{l}\text { A model presented by the } \\
\text { authors makes a mention of } \\
\text { visibility of content, quality of internet } \\
\text { system, quality of design, satisfied user, } \\
\text { user concentration leading to flow and } \\
\text { to e-loyalty. The authors have mentioned } \\
\text { flow as a state of the mind when an individual } \\
\text { is engrossed in an activity. }\end{array}$ & $\begin{array}{c}\text { The paper has conceptualized } \\
\text { hypotheses for testing in } \\
\text { the future. }\end{array}$ \\
\hline $\begin{array}{l}\text { (Koufaris \& Hampton- } \\
\text { Sosa, 2004) }\end{array}$ & $\begin{array}{l}\text { Good interface, and navigation } \\
\text { are equally important for customer } \\
\text { retention besides customer service, } \\
\text { price and enjoyment. Most web based } \\
\text { companies are providing features that } \\
\text { facilitate the customers experience. }\end{array}$ & $\begin{array}{l}\text { Most researchers study loyalty } \\
\text { of customers on the basis } \\
\text { of return visits, but in this } \\
\text { paper the authors have } \\
\text { studied the customer's return } \\
\text { intentions. }\end{array}$ \\
\hline (Gummerus et al., 2004) & $\begin{array}{l}\text { The paper speaks of factors } \\
\text { prime for e loyalty as } \\
\text { User interface, Responsiveness, } \\
\text { Security, Need fulfillment which } \\
\text { leads to trust and as an after } \\
\text { effect to satisfaction and loyalty }\end{array}$ & $\begin{array}{l}\text { The study was done on healthcare } \\
\text { industry websites. The authors } \\
\text { felt that website usability } \\
\text { factors should be studied } \\
\text { by researchers. }\end{array}$ \\
\hline (Srinivasan et al., 2002) & $\begin{array}{l}\text { The paper mentions factors that } \\
\text { have an impact of e loyalty } \\
\text { customization, contact interactivity, } \\
\text { care, community, convenience, } \\
\text { cultivation, choice, and character. } \\
\text { It also makes a mention on the customers } \\
\text { as word of mouth promotion and being } \\
\text { ready to pay more }\end{array}$ & $\begin{array}{l}\text { The paper claims to have } \\
\text { not studied variables at } \\
\text { customer level and } \\
\text { business level. }\end{array}$ \\
\hline (Palmer, 2002) & $\begin{array}{l}\text { Download speed, Navigability, } \\
\text { interactivity, responsive, content- } \\
\text { associated with greater perceived } \\
\text { success by site users }\end{array}$ & $\begin{array}{l}\text { The research was carried } \\
\text { out on undergraduate, } \\
\text { graduate and management } \\
\text { students. }\end{array}$ \\
\hline
\end{tabular}

Online Customer Loyalty has been classified by various thinkers as intentional, behavioural, cognitive, affective, conative. Intentional or attitudinal loyalty has been measured on the basis of intention to continue with the website, positive word of mouth. Behavioural loyalty is measured by the number of times the customer makes purchases in a year from the same site, the time spent on the site, number of referrals to the site. Cognitive, affective, conative and action loyalty is judged on the basis of preference vis-à-vis other sites, offers, services offered, performance.
Other factors that impact online loyalty are switching costs, the website value to the consumer, psychological factors like lethargy, mindset of the customers, determination. Basically the factors have been placed under different brackets as consumer characteristics, product or service characteristics, retailer characteristics, website characteristics and environmental characteristics. The researchers have also studied the effect of e loyalty that include increase in cross sales, share of wallet, promotes customers online word of mouth, reduction in sensitivity to price- ready to pay more, and re-purchase from the site. 


\section{CONCLUSION}

From the research papers / literature review, the common factors that impact e-loyalty or are important elements of online loyalty are security, convenience, personalization, discounts, offers, rewards, and trust. It has also been suggested by researchers that the angle of commitment, building strong relationships, cultural influences should also be studied. The studies undertaken by the researchers in the references were with limited target groups (for example- students) with convenience sampling, limited product/ service categories, specific areas/ cities. The future \{Bibliography\} research on online loyalty can be carried out such that it covers a more representative population.

\section{REFERENCES}

Chincholkar, S., \& Sonwaney, V. (2017). Website Attributes and its Impact on Online Consumer Buying Behaviour: An Empirical Study of Online Consumers in Mumbai Region. Indian Journal of Science and Technology, 10(47), 1-9. https://doi.org/10.17485/ ijst/2017/v10i47/119973

Accenture (2020). A New Era in Customer Engagement ecommerceDB (2020). Ecommerce in India, www. ecommerceDB.com

Giao, H. N. K., Vuong, B. N., \&t Quan, T. N. (2020). The influence of website quality on consumer's e-loyalty through the mediating role of e-trust and e-satisfaction: An evidence from online shopping in Vietnam. Uncertain Supply Chain Management, 8(2), 351-370. https://doi.org/10.5267/j.uscm.2019.11.004

Gummerus, J., Liljander, V., Pura, M., \&t Van Riel, A. (2004). Customer loyalty to content-based Web sites: The case of an online health-care service. Journal of Services Marketing, 18(3), 175-186. https://doi. org/10.1108/08876040410536486

India Brand Equity Foundation November Report (2020). www.ibef.org

Jamaludin, A., \&t Ahmad, F. (2015). The Influence of Website Trust and Website Quality on Intention to Purchase Online. 1(2).

Joe ilsever, D. (2007). Extending Models of Flow and E-Loyalty. Journal of Information Science and Technology, 4(2), 3-22.

Kassim, N., \&t Abdullah, N. A. (2008). Customer Loyalty in e-Commerce Settings: An Empirical Study. Electronic Markets, 18(3), 275-290. https://doi. org/10.1080/10196780802265843
Koufaris, M., \&t Hampton-Sosa, W. (2004). The development of initial trust in an online company by new customers. Information and Management, 41(3), 377-397. https://doi.org/10.1016/j.im.2003.08.004 Leong, M. K., Osman, S., Paim, L., \& Fazli, S. M. (2019). Enhancing consumer online engagement through consumer involvement: A case of airline and hospitality services in Malaysia. Management Science Letters, 9(6), 795-808. https://doi.org/10.5267/j.msl.2019.3.008

Nagvadia, J., \& Bhatt, V. (2020). a Study on Impact of Factors Influencing Online. An International Bilingual Peer Reviewed Refereed Research Journal, 10(40), 66-74.

Palmer, J. W. (2002). Web site usability, design, and performance metrics. Information Systems Research, 13(2), 151-167. https://doi.org/10.1287/ isre.13.2.151.88

Potdar, V., Joshi, S., Harish, R., Baskerville, R., \&t Wongthongtham, P. (2018). A process model for identifying online customer engagement patterns on Facebook brand pages. Information Technology and People, 31(2), 595-614. https://doi.org/10.1108/ITP-022017-0035

Rachbini, W. (2018). the Impact of Consumer Trust, Perceived Risk, Perceived Benefit on Purchase Intention and Purchase Decision. International Journal of Advanced Research, 6(1), 1036-1044. https://doi. org/10.21474/ijar01/6317

Reichheld, F. F., \&t Schefter, P. (2000). E-Loyalty: Your secret weapon on the web. Harvard Business Review, 78(4), 105-113.

Srinivasan, S. S., Anderson, R., \&t Ponnavolu, K. (2002). Customer loyalty in e-commerce: An exploration of its antecedents and consequences. Journal of Retailing, 78(1), 41-50. https://doi.org/10.1016/S00224359(01)00065-3

Tontini, G., da Silva, J. C., Beduschi, E. F. S., Zanin, E. R. M., \&t Marcon, M. de F. (2015). Nonlinear impact of online retail characteristics on customer satisfaction and loyalty. International Journal of Quality and Service Sciences, 7(2-3), 152-169. https://doi.org/10.1108/ IJQSS-02-2015-0021

Toufaily, E., Ricard, L., \& Perrien, J. (2013). Customer loyalty to a commercial website: Descriptive metaanalysis of the empirical literature and proposal of an integrative model. Journal of Business Research, 66(9), 1436-1447. https://doi.org/10.1016/j. jbusres.2012.05.011 